\title{
Effectiveness of Planned Teaching on Knowledge Regarding Contraceptive Methods among Postnatal Mothers Admitted in Maternity Hospitals
}

\author{
Archana S. Teltumbde \\ Department of Obstetrics \& Gynecology Nursing, Smt. Radhikabai Meghe Memorial College of \\ Nursing, Datta Meghe Institute of Medical Sciences (Deemed to be University) \\ Sawangi (Meghe) Wardha, Maharashtra, India.
}

\section{ABSTRACT}

Mother's health affects the health of her children, being a healthy mother is the best way to have healthy children. Women who are in poor health, poorly nourished or ignorant are more likely to give birth to unhealthy babies and often cannot provide adequate care, diminishing the chance the children will survive and thrive. Birth spacing, planned pregnancy can be improved and unwanted pregnancy; abortions can be avoided by proper use of contraceptive methods. Family planning is a method of thinking and a life style which is chosen voluntarily and according to the attitudes and responsible determination of the couples in order to promote the hygiene and convenience of the family. To assess the existing knowledge regarding contraceptive methods among postnatal mothers.2.To evaluate the effectiveness of Planned teaching on knowledge regarding contraceptive methods among postnatal mothers.3.To find out association between knowledge score and selected demographic variables. 100 samples were selected from post natal wards in selected hospitals of Maharashtra by Non probability convenient sampling technique. Pre Experimental research design one group Pre test and post test without control group design was used. Result: Findings revealed that in pre test majority of post natal mothers (66\%) had average knowledge regarding Contraceptive Methods. Mean percentage of knowledge score was (33.84\%) and in post test majority of postnatal mothers (48\%) had very good knowledge regarding Contraceptive Methods. Mean percentage of knowledge score was (70.56\%). Education, occupation and were found to be associated with knowledge of postnatal mothers none of the other variable were found significantly related with the knowledge of postnatal mothers. Thus it shows education also may be one of the contributing factor for the post natal mothers to acquire knowledge regarding Contraceptive Methods,. Contraceptive Methods is the most important method to all the postnatal mothers for spacing between the children, so the health education is very essential to all the antenatal and postnatal mothers and also mothers should be aware about contraceptive method during pregnancy to prevent the complication. The mean post-test knowledge score was found to be significantly higher than the mean pre-test knowledge scores.

\section{KEY WORDS: CONTRACEPTIVE METHODS, POSTNATAL MOTHER, PRIMIPARA, MULTIPARA, ABORTION}

\section{INTRODUCTION}

\section{Assumptions:}

- Postnatal mother may have inadequate knowledge regarding Contraceptive Methods.

Biosc Biotech Res Comm P-ISSN: 0974-6455 E-ISSN: 2321-4007

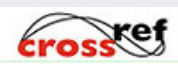

Identifiers and Pagination

Year: 2021 Vol: 14 No (9) Special Issue

Pages: $310-315$

This is an open access article under Creative

Commons License Attribn 4.0 Intl (CC-BY).

DOI: $h$ ttp://dx.doi.org/10.21786/bbrc/14.9.57

\section{Hypothesis:}

1. H1:- There will be significant difference between the pre-test and post test knowledge score regarding Contraceptive Methods among postnatal mothers

2. Ho :- There will be no significant difference between the pre-test and post test Knowledge score regarding Contraceptive Methods among postnatal mothers.

\section{METHODOLOGY}

Research Design:- Pre experimental one group pretest and posttest design

Setting of the study:- The study was conducted in selected hospitals of wardha

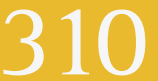


Sampling techinque: - Non probability convenient sampling

Sample : - Postnatal mothers

Sample size:- 100 samples

Criteria for sample selection:-

\section{I) Inclusion Criteria}

1. All postnatal mothers who are willing to participate in the study.

2. Those who are available at the time of data collection

\section{II) Exclusion Criteria}

1. Those having maternal complication.

\section{Description Of The Tools}

Section A :- Demographic variable

Table 1. Percentage wise distribution of postnatal mothers according to their demographic characteristics. $n=100$

Demographic Variables Frequency Percentage(\%)

\begin{tabular}{|lcc|}
\hline \multicolumn{3}{c|}{ Age(yrs) } \\
\hline $19-21$ yrs & 21 & 21 \\
$22-24$ yrs & 34 & 34 \\
$25-27$ yrs & 24 & 24 \\
$28-38$ yrs & 21 & 21 \\
\hline \multicolumn{3}{|c|}{ Place of residence } \\
\hline Urban & 46 \\
Rural & 54 & 46 \\
\hline \multicolumn{3}{|c|}{ Type of family } \\
\hline Nuclear & 31 & 31 \\
Joint & 55 & 55 \\
Extended & 14 & 14 \\
\hline
\end{tabular}

\begin{tabular}{lcc|} 
& Religion \\
\hline Hindu & 61 & 61 \\
Boudha & 21 & 21 \\
Muslim & 4 & 4 \\
Other & 14 & 14
\end{tabular}

\begin{tabular}{lcc}
\hline & Educational status of mother \\
\hline Illiterate & 3 & 3 \\
Primary & 22 & 22 \\
Secondary & 63 & 63 \\
Graduate & 9 & 9 \\
PG & 3 & 3 \\
\hline \multicolumn{3}{c}{ Occupation of the mother } \\
\hline Housewife & 50 & 50 \\
Service in Govt/Private & 14 & 14 \\
Daily Wages & 36 & 36 \\
Others & 0 & 0 \\
\hline \multicolumn{2}{c}{ Monthly family income(Rs) } \\
\hline 2000-5000 Rs & 46 & 46 \\
6000-9000 Rs & 27 & 27 \\
10000-13000 Rs & 15 & 15 \\
14000 Ct above & 12 & 12 \\
\hline
\end{tabular}

Section B:-Structured Questionnaire regarding knowledge on Contraceptive Methods.

\section{Result:- Major Finding Of The Study And Discussion}

The following are the major findings of the study.

- Distribution of postnatal mothers with regards to demographic variables.

- Distribution of postnatal mothers according to their age reveals that $21(21 \%)$ in $19-21$ years, $34(34 \%)$ in 22-24 years, 24(24\%) in 25-27 years and $21(21 \%)$ in 28-38 years.

- Distribution of postnatal mothers according to their place of residence reveals that $46(46 \%)$ in urban area and 54(54\%) in rural area.

- Distribution of postnatal mothers according to their type of family reveals that 31(31\%) in nuclear family, $55(55 \%)$ in joint family and $14(14 \%)$ in extended family.

- Distribution of postnatal mothers according to their religion reveals that $61(61 \%)$ in hindu, $21(21 \%)$ in boudha, 4(4\%) in muslim and 14(14\%) in others.

- Distribution of postnatal mothers according to their educational status of mother reveals that $3(3 \%)$ in illiterate, 22(22\%) in primary, 63(63\%) in secondary, $9(9 \%)$ in graduate and $3(3 \%)$ in post graduate.

- Distribution of postnatal mothers according to their occupation of the mother reveals that 50(50\%) in housewife, $14(14 \%)$ in service in govt. / private, $36(36 \%)$ in daily wages and $0(0 \%)$ in others.

- Distribution of postnatal mothers according to their monthly family income reveals that $46(46 \%)$ in 2000-5000 Rs., 27(27\%) in 6000-9000 Rs., 15(15\%) in 10000-13000 Rs. And 12(12\%) in 14000 \& above.

Table 2. Knowledge on Contraceptive Methods among postnatal mothers in Pre test $n=100$

\begin{tabular}{|c|c|c|c|c|}
\hline Level of knowledge & \multirow{2}{*}{$\begin{array}{c}\text { Score } \\
\text { score }\end{array}$} & Percentage & \multicolumn{2}{|c|}{ Pre Test } \\
\cline { 4 - 5 } & range & score & Frequency & Percentage \\
\hline Poor & $0-5$ & $0-20 \%$ & 15 & 15 \\
\hline Average & $6-10$ & $21-40 \%$ & 66 & 66 \\
\hline Good & $11-15$ & $41-60 \%$ & 17 & 17 \\
\hline Very Good & $16-20$ & $61-80 \%$ & 2 & 2 \\
\hline Excellent & $21-25$ & $>80 \%$ & 0 & 0 \\
\hline Minimum score & \multicolumn{5}{|c|}{19} \\
\hline Maximum score & \multicolumn{5}{|c|}{$8.46 \pm 2.76$} \\
\hline Mean score & \multicolumn{5}{|c|}{$33.84 \pm 11.04$} \\
\hline Mean \% & \multicolumn{5}{|c|}{} \\
\hline
\end{tabular}

The above table shows that $15(15 \%)$ of postnatal mothers were having poor level of knowledge score, 66(66\%) of them had average and $20(20 \%)$ of them had good level of knowledge score, $17(17 \%)$ had good and only2 (2\%) of them had very good level of knowledge score. The minimum score was 1 and the maximum score was 19 , the mean score was $8.46 \pm 2.76$ with a mean percentage score of $33.84 \pm 11.04$

Assessment of knowledge regarding Contraceptive Methods among postnatal mothers in selected hospital at wardha: The pre test findings shows that $15(15 \%)$ of postnatal mothers were having poor level of knowledge score, $66 \%$ of them had average and $20 \%$ of them had 
good level of knowledge score, 17\% had good and only $2 \%$ of them had very good level of knowledge score. The minimum score was 1 and the maximum score was 19 , the mean score was $8.46 \pm 2.76$ with a mean percentage score of $33.84 \pm 11.04$. The post test findings shows that $3(3 \%)$ of postnatal mothers were having average level of knowledge score, 24\% had good, 48\% had very good and $25 \%$ of them had excellent level of knowledge score. The minimum score was 10 and the maximum score was 25, the mean score was $17.64 \pm 3.45$ with a mean percentage score of $70.56 \pm 13.81$. After assessing pre test and post test it shows that after planned teaching there was increase in post test knowledge score (Chandhick 2003).

Table 3. Knowledge on Contraceptive Methods among postnatal mothers in Post test $n=100$

\begin{tabular}{l|c|c|c|c|}
\hline \multirow{2}{*}{$\begin{array}{l}\text { Level of knowledge } \\
\text { score }\end{array}$} & Score range & Percentage score & \multicolumn{2}{|c}{ Post Test } \\
\cline { 3 - 5 } & & & Frequency & Percentage \\
\hline Poor & $0-5$ & $0-20 \%$ & 0 & 0 \\
\hline Average & $6-10$ & $21-40 \%$ & 3 & 3 \\
\hline Good & $11-15$ & $41-60 \%$ & 24 & 24 \\
\hline Very Good & $16-20$ & $61-80 \%$ & 48 & 48 \\
\hline Excellent & $21-25$ & $>80 \%$ & 25 & 25 \\
\hline Minimum score & & \multicolumn{3}{|c}{25} \\
\hline Maximum score & & 10 & \\
\hline Mean score & & $70.56 \pm 13.81$
\end{tabular}

The above table shows that 15(15\%) of postnatal mothers were having poor level of knowledge score, $66(66 \%)$ of them had average and $20(20 \%)$ of them had good level of knowledge score, $17(17 \%)$ had good and only2( $2 \%$ ) of them had very good level of knowledge score. The minimum score was 1 and the maximum score was 19 , the mean score was $8.46 \pm 2.76$ with a mean percentage score of $33.84 \pm 11.04$.

Table 3a. Effectiveness of planed teaching on Contraceptive Methods of postnatal mothers $\mathrm{n}=10$

\begin{tabular}{l|c|c|c|c|}
\multirow{2}{*}{$\begin{array}{l}\text { Level of knowledge } \\
\text { score }\end{array}$} & \multirow{2}{*}{$\begin{array}{c}\text { Score } \\
\text { range }\end{array}$} & \multirow{2}{*}{$\begin{array}{c}\text { Percentage } \\
\text { score }\end{array}$} & \multicolumn{2}{|c|}{ Post Test } \\
\cline { 4 - 5 } & & Pre Test & Post Test \\
\hline Poor & $0-5$ & $0-20 \%$ & $15(15 \%)$ & $0(0 \%)$ \\
\hline Average & $6-10$ & $21-40 \%$ & $66(66 \%)$ & $3(3 \%)$ \\
\hline Good & $11-15$ & $41-60 \%$ & $17(17 \%)$ & $24(24 \%)$ \\
\hline Very Good & $16-20$ & $61-80 \%$ & $2(2 \%)$ & $48(48 \%)$ \\
\hline Excellent & $21-25$ & $>80 \%$ & $0(0 \%)$ & $25(25 \%)$ \\
\hline & & Minimum score & 1 & 10 \\
\hline & & Maximum score & 19 & 25 \\
\hline & & Mean score & $8.46 \pm 2.76$ & $17.64 \pm 3.45$ \\
\hline & & Mean \% & $33.84 \pm 11.04$ & $70.56 \pm 13.81$ \\
\hline
\end{tabular}

The above table shows that 3(3\%) of postnatal mothers were having average level of knowledge score, $24(24 \%)$ had good, $48(48 \%)$ had very good and $25(25 \%)$ of them had excellent level of knowledge score. The minimum score was 10 and the maximum score was 25 , the mean score was $17.64 \pm 3.45$ with a mean percentage score of $70.56 \pm 13.81$.

\section{Association Of Knowledge Score In Relation To Demographic Variables.}

\section{RESULTS AND DISCUSSION}

A study on contraceptive knowledge, practice and utilization of service in rural area of India was conducted among 1,17,465 eligible women from selected 28 districts, out of 1,17,465 eligible women 14,276 were using contraceptives and 17,082 were not using any family 
methods (Jain et al., 1999). Among contraceptive users only 26 percent of women were using spacing methods. Almost all women (98.8\%) were using a contraceptive method with the knowledge of their husband and had their support for continuing the same. The most common reason given for not using any family planning method was 'family not completed (34.6\%), and fear of side effects (10\%).10 (Hiller et al., 2002).

Graph 1. Effectiveness of planned teaching in pre and post test of knowledge on Contraceptive Methods among postnatal mothers

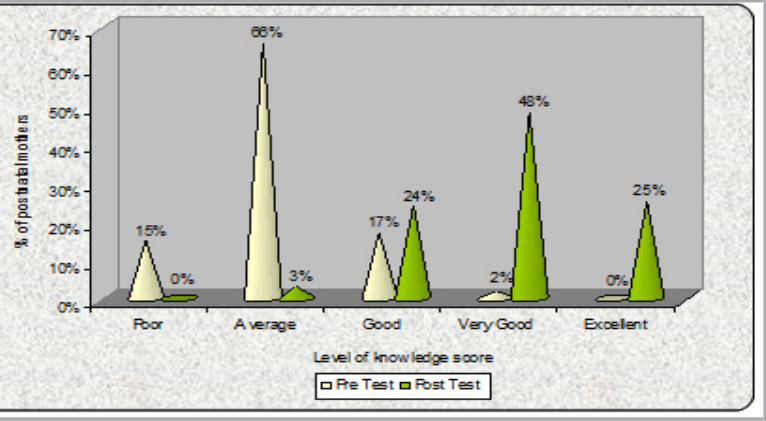

Table 4. Association of knowledge score in relation to age in years of the postnatal mothers $n=100$

\begin{tabular}{|c|c|c|c|c|}
\hline Age(Years) & $\begin{array}{c}\text { No. of } \\
\text { postnatal } \\
\text { mothers }\end{array}$ & $\begin{array}{c}\text { Mean } \\
\text { knowledge } \\
\text { score }\end{array}$ & F-value & p-value \\
\hline $19-21$ yrs & 21 & $17.23 \pm 3.76$ & 0.47 & $\begin{array}{c}0.700 \\
\text { NS,p }>0.05\end{array}$ \\
\hline $22-24$ yrs & 34 & $17.38 \pm 2.77$ & & \\
\hline $25-27$ yrs & 24 & $17.70 \pm 3.62$ & & \\
\hline $28-38$ yrs & 21 & $18.38 \pm 4.01$ & & \\
\hline
\end{tabular}

This table shows the association of knowledge scores with the age in years of postnatal mothers. The tabulated ' $F$ ' values was $2.68(\mathrm{df}=3,96)$ which is higher than the calculated 'F' i.e. 0.47 at $5 \%$ level of significance. Also the calculated ' $\mathrm{p}$ ' $=0.700$ which was much higher than the acceptable level of significance i.e. 'p'=0.05. Hence it is interpreted that age in years of postnatal mothers in selected hospitals of Wardha is not associated with their knowledge scores.

Table 5. Association of knowledge score in relation to place of residence of the postnatal mothers $n=100$

\begin{tabular}{|l|c|c|c|c|}
\hline Place of residence & No. of postnatal mothers & Mean knowledge score & t-value & p-value \\
\hline Urban & 46 & $17.95 \pm 3.88$ & 0.84 & $\begin{array}{c}0.40 \\
\text { NS, } p>0.05\end{array}$ \\
\hline Rural & 54 & $17.37 \pm 3.04$ & & \\
\hline
\end{tabular}

This table shows the association of knowledge scores with the place of residence of postnatal mothers. The tabulated ' $t$ ' values was $1.98(\mathrm{df}=98)$ which is higher than the calculated ' $t$ ' i.e 0.84 at $5 \%$ level of significance. Also the calculated ' $p$ ' $=0.40$ which was much higher than the acceptable level of significance i.e. ' $p$ ' $=0.05$. Hence it is interpreted that place of residence of postnatal mothers in selected hospitals of Wardha is not associated with their knowledge scores.

Table 6. Association of knowledge score in relation to type of family of the postnatal mothers $n=100$

\begin{tabular}{|l|c|c|c|c|}
\hline Type of family & No. of postnatal mothers & Mean knowledge score & t-value & p-value \\
\hline Nuclear & 31 & $16.61 \pm 4$ & & \\
\hline Joint & 55 & $18.12 \pm 3.09$ & 2.03 & 0.13 \\
\hline Extended & 14 & $18 \pm 3.21$ & & NS,p>0.05 \\
\hline
\end{tabular}

This table shows the association of knowledge scores with the type of family of postnatal mothers. The tabulated 'F' values was 3.07( $\mathrm{df}=2,97)$ which is higher than the calculated ' $F$ ' i.e 2.03 at 5\% level of significance. Also the calculated ' $p$ ' $=0.13$ which was much higher than the acceptable level of significance i.e. ' $p$ ' $=0.05$. Hence it is interpreted that type of family of postnatal mothers in selected hospitals of Wardha is not associated with their knowledge scores. 
Table 7. Association of knowledge score in relation to religion of the postnatal mothers $n=100$

\begin{tabular}{|l|c|c|c|c|}
\hline Religion & No. of postnatal mothers & Mean knowledge score & t-value & p-value \\
\hline Hindu & 61 & $17.65 \pm 3.25$ & & \\
\hline Boudha & 21 & $18.33 \pm 3.95$ & 0.78 & 0.50 \\
\hline Muslim & 4 & $17.75 \pm 2.75$ & & NS, $>0.05$ \\
\hline Others & 14 & $16.50 \pm 3.75$ & & \\
\hline
\end{tabular}

This table shows the association of knowledge scores with the religion of postnatal mothers. The tabulated 'F' values was $2.68(\mathrm{df}=3,96)$ which is higher than the calculated ' $\mathrm{F}$ ' i.e 0.78 at $5 \%$ level of significance. Also the calculated ' $p$ ' $=0.50$ which was much higher than the acceptable level of significance i.e. 'p' $=0.05$. Hence it is interpreted that religion of postnatal mothers in selected hospitals of Wardha is not associated with their knowledge scores.

Table 8. Association of knowledge score in relation to educational status of the postnatal mothers $n=100$

\begin{tabular}{|l|c|c|c|c|}
\hline Educational Status & No. of postnatal mothers & Mean knowledge score & t-value & p-value \\
\hline Illiterate & 3 & $13.66 \pm 3.21$ & 5.35 & 0.001 \\
\hline Primary & 22 & $17.77 \pm 3.10$ & & S,p<0.05 \\
\hline Secondary & 63 & $17.11 \pm 3.26$ & & \\
\hline Graduate & 9 & $21.44 \pm 2.87$ & & \\
\hline PG & 3 & $20.33 \pm 2.51$ & & \\
\hline
\end{tabular}

This table shows the association of knowledge scores with the educational status of postnatal mothers. The tabulated ' $F$ ' values was $2.45(\mathrm{df}=4,95)$ which is less than the calculated ' $F$ ' i.e 5.35 at $5 \%$ level of significance. Also the calculated ' $p$ ' $=0.001$ which was much less than the acceptable level of significance i.e. ' $p$ ' $=0.05$. Hence it is interpreted that educational status of postnatal mothers in selected hospitals of Wardha is statistically associated with their knowledge scores

Table 9. Association of knowledge score in relation to occupational status of the postnatal mothers $n=100$

\begin{tabular}{|c|c|c|c|c|}
\hline Religion & No. of postnatal mothers & Mean knowledge score & t-value & p-value \\
\hline Housewife & 50 & $18.26 \pm 3.31$ & & \\
\hline Service in Govt/ & 14 & $19.57 \pm 2.56$ & 7.87 & 0.001 \\
\hline $\begin{array}{l}\text { Private } \\
\text { Daily Wages }\end{array}$ & 36 & $16.02 \pm 3.34$ & & $\mathrm{~S}, \mathrm{p}<0.05$ \\
\hline Others & 0 & $0 \pm 0$ & & \\
\hline $\begin{array}{l}\text { This table shows th } \\
\text { tabulated 'F' values } \\
\text { Also the calculated } \\
\text { it is interpreted tha } \\
\text { associated with the }\end{array}$ & $\begin{array}{l}\text { ciation of knowledge scores } \\
.07(\mathrm{df}=2,97) \text { which is less than } \\
001 \text { which was much less than } \\
\text { pational status of postnatal } \mathrm{m} \\
\text { wledge scores }\end{array}$ & $\begin{array}{l}\text { with the educational status of } \\
\text { the calculated 'F' i.e } 7.87 \text { at } \\
\text { the acceptable level of signific } \\
\text { nothers in selected hospitals o }\end{array}$ & $\begin{array}{l}\text { postnatal } \\
\% \text { level of } \\
\text { ance i.e. 'p } \\
\text { f Wardha i }\end{array}$ & $\begin{array}{l}\text { mothers. The } \\
\text { significance. } \\
=0.05 \text {. Hence } \\
\text { statistically }\end{array}$ \\
\hline
\end{tabular}

A randomized controlled trial on 139 adolescents teenage mothers was conducted to assess their knowledge of contraception, infant vaccination, and breastfeeding .A structured postnatal home visits by nurse-midwives $(n=65)$ or not $(n=71)$ assessment interviews were done for 6 months postpartum (Ramachandran et al., 1983). Study concluded that postnatal home visits were associated with a reduction in adverse neonatal outcomes and a 
significant increase in contraception knowledge was improved, This study supported to present study sot he planned teaching was effective in improving the knowledge of postnatal mothers Contraceptive Methods (Rastak et al., 2005).

Table 10. Association of knowledge score in relation to monthly family income of the postnatal mothers $n=100$

\begin{tabular}{|l|c|c|c|c|}
\hline $\begin{array}{l}\text { Monthly family } \\
\text { income(Rs) }\end{array}$ & No. of postnatal mothers & Mean knowledge score & t-value & p-value \\
\hline 2000-5000 Rs & 46 & $17.15 \pm 3.57$ & & \\
\hline $6000-9000 \mathrm{Rs}$ & 27 & $17.85 \pm 3.63$ & 1.33 & 0.26 \\
\hline $10000-13000 \mathrm{Rs}$ & 15 & $17.40 \pm 3.18$ & & $\mathrm{NS}, \mathrm{p}>0.05$ \\
\hline 14000 \&t above & 12 & $19.33 \pm 2.60$ & & \\
\hline
\end{tabular}

This table shows the association of knowledge scores with monthly family income(Rs) of postnatal mothers. The tabulated 'F' values was $2.68(\mathrm{df}=3,96)$ which is higher than the calculated 'F' i.e 1.33 at $5 \%$ level of significance. Also the calculated ' $p$ ' $=0.26$ which was much higher than the acceptable level of significance i.e. ' $p$ '=0.05. Hence it is interpreted that monthly family income(Rs) of postnatal mothers in selected hospitals of Wardha is not associated with their knowledge scores

Table 11. Association of knowledge score in relation to parity of the postnatal mothers $n=100$

\begin{tabular}{|l|c|c|c|c|}
\hline Parity & No. of postnatal mothers & Mean knowledge score & t-value & p-value \\
\hline Primipara & 65 & $17.14 \pm 3.35$ & 2.00 & 0.04 \\
\hline Multipara & 35 & $18.57 \pm 3.48$ & & S,p $<0.05$ \\
\hline
\end{tabular}

This table shows the association of knowledge scores with the parity of postnatal mothers. The tabulated ' $t$ ' values was $2.00(\mathrm{df}=98)$ which is less than the calculated ' $t$ ' i.e 2.00 at $5 \%$ level of significance. Also the calculated ' $p$ ' $=0.040$ which was less than the acceptable level of significance i.e. 'p' $=0.05$. Hence it is interpreted that parity of postnatal mothers in selected hospitals of Wardha is associated with their knowledge scores.

\section{CONCLUSION}

Based on the analysis of findings of the study, the following inference was drawn. There was evident increase in the knowledge scores in all the areas included in the study after administration of the plan teaching. The actual gain score was significantly higher in the areas of Contraceptive Methods and indicated more scope for improving in the area of knowledge of Contraceptive Methods Thus the plan teaching was effective and while the gain in knowledge scores. It was found that there was deficit in knowledge about Contraceptive Methods. Paired' test was computed to assess the effectiveness of the planned teaching in terms of knowledge gain. A significant difference in means was found in knowledge scores between pre-test $\mathrm{Ct}$ post-test. The mean post-test knowledge score was found to be significantly higher than the mean pre-test knowledge scores.

\section{REFERENCES}

Chandhick, N., Dhillon, B.S., Kambo, I. and Saxena, N.C., (2003). Contraceptive knowledge, practices and utilization of services in the rural areas of India (an
ICMR task force study). Indian Journal of Medical Sciences, 57(7), pp.303-310.

Hiller, J.E., Griffith, E. and Jenner, F., (2002). Education for contraceptive use by women after childbirth. Cochrane Database of systematic reviews, (3).

Jefferson, G., Standardization of Contents of Ob-Gyn Ultrasound Reports.

Jain, S., Singh, J.V., Bhatnagar, M., Garg, S.K., Chopra, H. and Bajpai, S.K., (1999). Attitude of rural women towards contraceptive and its use. Indian journal of maternal and child health: official publication of Indian Maternal and Child Health Association, 10(1), pp.1819.

Rastak, L., (2005). Correlation between sociodemographic characteristics and contraceptive methods. Journal of Shahrekord Uuniversity of Medical Sciences, 7.

Ramachandran, L. and Dharmalingam, T., (1983). A textbook of health education. Vikas pub..

Whitaker, A.K., Johnson, L.M., Harwood, B., Chiappetta, L., Creinin, M.D. and Gold, M.A., (2008). Adolescent and young adult women's knowledge of and attitudes toward the intrauterine device. Contraception, 78(3), pp.211-217. 